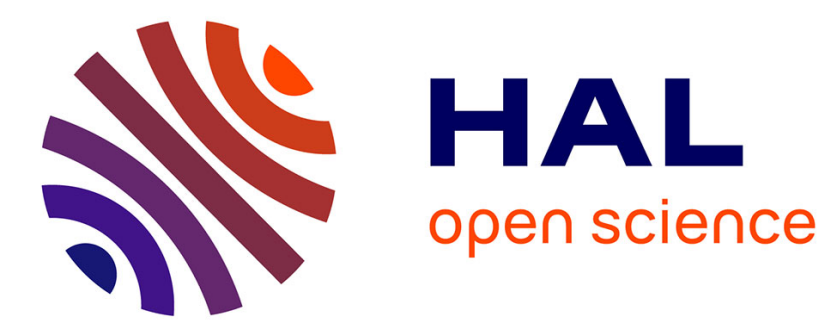

\title{
Risk Factors for Late Presentation for Care among HIV-Infected Patients in Guadeloupe: 1988-2009
}

\author{
Narcisse Elenga, Marie-Therese Geroger-Sow, Mathieu Nacher
}

\section{To cite this version:}

Narcisse Elenga, Marie-Therese Geroger-Sow, Mathieu Nacher. Risk Factors for Late Presentation for Care among HIV-Infected Patients in Guadeloupe: 1988-2009. J AIDS Clinic Res, 2012, 3 (7), pp.1000166. 10.4172/2155-6113.1000166 . inserm-00915176

\section{HAL Id: inserm-00915176 https://www.hal.inserm.fr/inserm-00915176}

Submitted on 6 Dec 2013

HAL is a multi-disciplinary open access archive for the deposit and dissemination of scientific research documents, whether they are published or not. The documents may come from teaching and research institutions in France or abroad, or from public or private research centers.
L'archive ouverte pluridisciplinaire HAL, est destinée au dépôt et à la diffusion de documents scientifiques de niveau recherche, publiés ou non, émanant des établissements d'enseignement et de recherche français ou étrangers, des laboratoires publics ou privés. 


\title{
Risk Factors for Late Presentation for Care among HIV-Infected Patients in Guadeloupe: 1988-2009
}

Elenga Narcisse ${ }^{1 *}$, Georger-Sow Marie-Therese ${ }^{2}$ and Nacher Mathieu ${ }^{3}$

${ }^{1}$ Service de Pediatrie, Centre Hospitalier Andree Rosemon, Rue des Flamboyants, BP 6006-97306 Cayenne Cedex, French Guiana, France

${ }^{2}$ Coordination Regionale VIH (COREVIH) Cayenne, Guyane, Centre hospitalier de Cayenne, Andree Rosemon, BP 6006-97306 Cayenne Cedex, Guyana, France ${ }^{3}$ Coordination Regionale VIH (COREVIH) Guadeloupe CHU de Pointe-a-Pitre/Abymes, Cayenne, Guyana, France

\begin{abstract}
Objective: The objective of this study was to identify the factors associated with presentation for care with CD4 cell count $<200 / \mathrm{mm}^{3}$.

Design: A Retrospective monocentric cohort study of the Guadeloupe section of French Hospital Database for HIV was conducted.

Methods: Group 1 Cohort (CD4 <200/mm³ n=1076), Group 2 (CD4 200-500, n=973) and Group 3 (CD4 > $500 /$ $\mathrm{mm}^{3}, \mathrm{n}=627$ ) patients were included between 1 January 1988 and 31 December 2009. Factors associated with late presentation (CD4 count $<200$ cells $/ \mu \mathrm{L}$ ) were assessed using descriptive statistics and ordered multivariable logistic regression.

Results: At the time of diagnosis, $40.21 \%$ of patients had than less 200 CD4 lymphocytes $/ \mathrm{mm}^{3}$. Age older than 30 years OR: 1.55[1.14-2.10], $p=0.005$, male gender OR: 1.83[1.58-2.12], $p<0.0001$, access to care before 1992 OR: 1.56[1.03-2.02], $p=0.038$ and alcohol use OR: $8.80[2.26-34.36], p=0.002$ were independently associated with a low CD4 cell count.

Conclusion: The findings of this study (underline the need to expand HIV testing beyond the usual facilities) may be of value in helping to achieve earlier access to treatment in HIV-infected patients in order to minimize the individual risk of morbidity and mortality.
\end{abstract}

Keywords: HIV; CD4 cell count; Diagnosis; Late presentation; Guadeloupe

\section{Introduction}

After Sub-Saharan Africa, the Caribbean is the world's region most affected by HIV/AIDS. The French-American Departments (Guadeloupe Martinique, Guiana), FAD, are located in the heart of this region. Although lower than in other states of the Caribbean, AIDS incidence is much higher than in mainland France (up to four times more in Guadeloupe) [1,2].

Guadeloupe is part of the French overseas territories, which has the largest number of persons living with HIV/AIDS. Transmission is mostly heterosexual, and the proportion of women infected is high, almost half of all those infected. Moreover, in Guadeloupe a large proportion of patients are foreigners (mainly from Haiti). Countryspecific risk analyses are important to effectively guide public health interventions. Antiretroviral therapy reduces mortality and morbidity in HIV-infected individuals most markedly when initiated early, before advanced immunodeficiency has developed. Late presentation for diagnosis and care remains a significant challenge.

In the literature, more than 20 different definitions have been cited for a late presenter [3]. Recently a European consensus definition of late presentation (CD4 count $<350$ cells $/ \mathrm{mL}$ or clinical AIDS) and presentation with advanced HIV disease (CD4 count $<200$ cells $/ \mathrm{mL}$ or clinical AIDS) was published to facilitate cross-country comparisons of trends and results of targeted interventions [4]. The United Nations does not currently publish HIV/AIDS epidemiological fact sheets for Guadeloupe and thus specific HIV/AIDS data are not available in the scientific publications for this territory. HIV diagnosis and presentation to appropriate medical care during early stages of disease has substantial clinical and public health benefits.
The objective of this study was to determine the factors associated with presentation for care with CD 4 cell count $<200 / \mathrm{mm}^{3}$ in Guadeloupe from the start of 1988 to the end of 2009.

\section{Methods}

\section{Guadeloupe sociodemographics}

The French Department Guadeloupe (French West Indies) has been part of France since 1946. Even though it is located in the Region of the Americas, it is given special protection and granted structural funds from Europe devoted to assist developing European regions.

Guadeloupe is an archipelago of eight inhabited islands; the two largest, separated by a sound, are Basse-Terre and Grande-Terre. The other islands include Les Saintes and Marie Galante to the south, Desirade to the east, and the French section of Saint Martin and Saint Barthelemy some $230 \mathrm{~km}$ to the north.

The population of Guadeloupe remained stable during the 1960 and

*Corresponding author: Elenga N, MD, Service de Pédiatrie, Centre hospitalie Andree Rosemon, Rue des Flamboyants, BP 6006-97306 Cayenne cedex Guyane Francaise, France, Tel: +594 694978 048; Fax: +594 594 394819; E-mail: elengafr@yahoo.fr

Received July 24, 2012; Accepted September 01, 2012; Published September 04,2012

Citation: Elenga N, Georger-Sow M-T, Nacher M (2012) Risk Factors for Late Presentation for Care among HIV-Infected Patients in Guadeloupe: 1988-2009. J AIDS Clinic Res 3:166. doi:10.4172/2155-6113.1000166

Copyright: (C) 2012 Elenga N, et al. This is an open-access article distributed unde the terms of the Creative Commons Attribution License, which permits unrestricted use, distribution, and reproduction in any medium, provided the original author and source are credited. 
1980 decades. Considerable migration to France occurred during this period, mainly as a consequence of lack of work, followed by a vigorous, although declining birth rate. Since the mid-1980s, and coinciding with declining employment rates in France, adults and retirees have returned to Guadeloupe.

The 1990 census showed an average annual population growth of $2.1 \%$ in Guadeloupe for the 1982-1990 period. This growth continues, and in 2009, the population density was 248 inhabitants per $\mathrm{km}^{2}$. Population estimates in 2009 were 404,394 inhabitants, the population younger under 25 years representing $35.8 \%$. In 2009, life expectancy in Guadeloupe was 83.4 years for women and 75.6 for men [5].

Immigration from neighbouring developing countries accounts for part of the growth population. Guadeloupe, being a free port with a thriving tourism industry, has had a four-fold increase in the number of inhabitants in the past eight years; half of the population is foreign.

\section{Data sources}

HIV-positive patients followed in University hospital of Pointe-aPitre and Basse Terre hospitals since January $1^{\text {st }} 1988$ and St. Martin Hospital since January $1^{\text {st }} 1992$ until $31^{\text {st }}$ December 2009 were enrolled in the Guadeloupe section of French Hospital Database for HIV (GFHDH). Time-independent variables such as sex, nationality and mode of transmission, and time-dependent variables such as age, CD4 counts, HIV-1 viral loads, treatments, and clinical events are routinely entered in the database by trained Clinical Studies Technicians. Patients included in the GFHDH give informed consent to the use of their data. Their identity is encrypted before the data are sent to the Ministry of Health and the Institut National de la Recherche Medicale (INSERM) which centralize data from Centres for Information and Care of HIV (CISIH) throughout France. This data collection is approved by the Commission Nationale Informatique et Libertes (CNIL), a national committee that oversees research data.

\section{Definition of late presentation for diagnosis}

Late diagnosis was defined as having a CD4 count $<200$ cells/ $\mathrm{mL}$ or clinical AIDS (a CDC category $\mathrm{C}$ event) at the time of the first presentation for care.

\section{Eligibility criteria}

Patients were eligible for the study if they had a CD4 cell count and were aged $\geq 18$ years, had initiated care in one of the study centres between 1988 to 2009. Patients with no CD4 cell count at the enrolment were excluded.

\section{Variables}

We evaluated the demographic, clinical, biological and social characteristics of the patients included in the study. Demographic data included age at enrolment ( $\leq 30$ years, $>30$ years), gender, nationality (French, foreign) and HIV transmission category. We stratified HIV transmission into four categories, in hierarchical order: injection drug users (IDU), men who have sex with men (MSM), heterosexual contact, and other. AIDS-defining diseases at initial presentation to care were identified using the Expanded European AIDS definition [4]. We created five categories for period of inclusion: 1988-1991, 1992-1995, 1996-1999, 2000-2003, and 2004-2009.

\section{Statistical analysis}

The included population was stratified into 3 categories according to $\mathrm{CD} 4$ cell count at the first contact with the hospital. Group 1 patients with CD4 $<200$ cells $/ \mathrm{mm}^{3}$ ( $\left.\mathrm{n}=1076,40.21 \%\right)$, Group 2 patients with $200<\mathrm{CD} 4<500$ cells $/ \mathrm{mm}^{3}(\mathrm{n}=973,36.36 \%)$ and Group 3 patients with CD4 $\geq 500$ cells $/ \mathrm{mm}^{3}$ ( $\left.\mathrm{n}=627,23.43 \%\right)$. Comparisons were made by chi-square test or Fisher's exact test for categorical variables, and MannWhitney test for continuous variables.

The factors associated with presentation for care with CD4 $<200$ cells $/ \mathrm{mm}^{3}$ were analysed by ordered logistic regression based on odds ratios (OR). For all tests performed, a p value of 0.05 or less was considered as statistically significant. The data were analysed with STATA 10.0 (Stata Corp LP, College Station, TX, USA). We include in our final model the covariates that were associated with the outcome and other factors associated with late presentation for care, according to literature.

\section{Results}

Among 3,329 patients enrolled in the Guadeloupe section of the French Hospital Database on HIV infection in the study period, 2,676 ( 1,108 females and 1,568 males $p=0.000)$ were eligible. Of them 1,076 patients had CD4 cell count below 200/ $\mathrm{mm}^{3}, 973$ patients in Group 2 and 627 in Group 3. Mean age was $36.9 \pm 13$ years (39.9 \pm 12.5 in Group $1,36.7 \pm 12.9$ in Group 2 and $35.6 \pm 13.2$ in Group $3 p=0.000$ ).

Five hundred and three patients developed opportunistic infections: pneumocystis carinii pneumonia $(\mathrm{n}=140)$, tuberculosis $(\mathrm{n}=58)$, cerebral toxoplasmosis $(n=94)$, oesophageal candidosis $(n=503)$, Kaposi's sarcoma $(n=17)$, lymphoma $(n=9)$, progressive multifocal leucoencephalopathy $(\mathrm{n}=32)$, pulmonary or meningeal cryptococcosis $(\mathrm{n}=19)$, disseminated histoplasmosis $(\mathrm{n}=3)$.

In multivariate ordered logistic regression, factors associated with presentation for care with CD 4 cells count $<200 / \mathrm{mm}^{3}$ were: age older than 30 years, male gender, access to care before 1992 and alcohol use (Table 1). The proportion of AIDS (or CDC classification stage C) was $18.9 \%$.

\section{Discussion}

The main objective of this study was to analyze, in HIV-infected patients from Guadeloupe (French West Indies), the risk factors associated with late presentation to care. From 1988 to 2009 in Guadeloupe, $40.21 \%$ of HIV infected patients had CD 4 cell count $<200$ / $\mathrm{mm}^{3}$. This proportion increase between 1988-1991 and 1992-1995, and remained stable between 1992-1995 and 1996-1999, then decreased between 1996-1999 and 2000-2003 and has remained again stable since 2000-2003. This result suggests that, despite public health efforts focused on anonymous, free screening centers, prevention counselling, and access to Highly Active Antiretroviral Therapy (HAART), the proportion of HIV-infected patients who present for care with low CD4 count remains high. This finding is consistent with data from other investigators [6-10].

We observed an increase in mean age at first presentation for care over time. As in previous studies [6-10], we found that age was strongly associated with both increased risk of first presentation for care with low CD4 cell count. This may be due to a greater perception of risk of HIV infection in younger persons influenced by public information [11]. Conversely, older patients consider themselves less at risk of infection, with perhaps a false perception of protection [12]. The association of male gender with late presentation for care is might be attributed to the fact that women are systematically tested for HIV during pregnancy. Indeed, the pregnancy is nevertheless a special moment for medical monitoring; women are particularly compliant during their pregnancy, 
Citation: Elenga N, Georger-Sow M-T, Nacher M (2012) Risk Factors for Late Presentation for Care among HIV-Infected Patients in Guadeloupe: 19882009. J AIDS Clinic Res 3:166. doi:10.4172/2155-6113.1000166

Page 3 of 4

\begin{tabular}{|c|c|c|c|c|c|c|}
\hline Variables & CD4<200 & CD4 200-500 & CD4 $>=500$ & Univariate OR (CI95\%) & Adjusted OR $(95 \% \mathrm{Cl})^{*}$ & $p$ \\
\hline & $n(\%)$ & $n(\%)$ & $n(\%)$ & & & \\
\hline \multicolumn{7}{|l|}{ Age } \\
\hline$>30$ & $200(20)$ & $143(15)$ & 102(17) & 1 & & \\
\hline$\leq 30$ & $55(5)$ & 101(10) & $60(10)$ & $1.81(1.35-2.45)$ & $1.55(1.14-2.10)$ & 0.005 \\
\hline Missed data & $771(75)$ & $739(75)$ & $434(73)$ & $1.14(0.94-1.39)$ & $1.45(1.03-2.02)$ & 0.03 \\
\hline \multicolumn{7}{|l|}{ Gender } \\
\hline Female & $332(32)$ & $446(45)$ & $307(52)$ & 1 & & \\
\hline Male & $694(68)$ & $537(55)$ & $289(48)$ & $1.81(1.57-2.10)$ & $1.83(1.58-2.12)$ & $<0.0001$ \\
\hline \multicolumn{7}{|l|}{ HIV diagnosis period } \\
\hline 2004-2009 & $119(12)$ & $114(11)$ & $72(12)$ & 1 & & \\
\hline $2000-2003$ & 19519) & 232(24) & 102(17) & $0.97(0.75-1.25)$ & $1.04(0.80-1.36)$ & 0.75 \\
\hline 1996-1999 & $256(25)$ & $225(23)$ & $121(20)$ & $0.85(0.66-1.10)$ & $0.90(0.70-1.17)$ & 0.45 \\
\hline 1992-1995 & $281(27)$ & $234(24)$ & $178(30)$ & $1.00(0.78-1.23)$ & $1.18(0.91-1.55)$ & 0.22 \\
\hline 1988-1991 & $175(17)$ & $178(18)$ & $123(21)$ & $1.11(0.85-1.45)$ & $1.56(1.03-2.02)$ & 0.038 \\
\hline \multicolumn{7}{|l|}{$\begin{array}{l}\text { Route of HIV- } \\
\text { transmission }\end{array}$} \\
\hline Heterosexual & $604(59)$ & $551(56)$ & $375(63)$ & 1 & & \\
\hline Homo-bisexual & $113(11)$ & $96(10)$ & $67(11)$ & $1.04(0.89-1.22)$ & $1.10(0.90-1.24)$ & 0.47 \\
\hline Transfusion/Haemophilia & $18(2)$ & $14(1)$ & $6(1)$ & $0.71(0.39-1.31)$ & $0.62(0.33-1.16)$ & 0.14 \\
\hline Other/undetermined & $281(28)$ & $320(33)$ & $147(25)$ & dropped/collinearity & & \\
\hline \multicolumn{7}{|l|}{ Addiction } \\
\hline No addiction & 1014(99) & 972(99) & $584(98)$ & 1 & & \\
\hline Reported & $12(1)$ & $11(1)$ & 12(2) & $1.49(0.79-2.80)$ & $1.77(0.94-3.34)$ & 0.078 \\
\hline \multicolumn{7}{|l|}{ Alcohol use } \\
\hline No alcohool & 1026(100) & 980(99 & $590(99)$ & 1 & & \\
\hline Reported & $0(0)$ & $3(1)$ & $6(1)$ & $7.68(2.00-29.47)$ & $8.80(2.26-34.36)$ & 0.002 \\
\hline \multicolumn{7}{|l|}{ Depression } \\
\hline No depression & 1018(99) & $981(99)$ & $594(99)$ & 1 & & \\
\hline Reported & $8(1)$ & $2(1)$ & $2(1)$ & $0.37(0.11-1.22)$ & $0.38(0.11-1.27)$ & 0.12 \\
\hline
\end{tabular}

* Obtained using ordered logistic regression with indicator variables for non binary variables.

Table 1: Risk factors associated with late presentation for care in HIV-infected patients in Guadeloupe (West French Indies) from 1988 to 2009.

because their priority is the protection of the child's health. In contrast, men are more likely to delay testing until clinical symptoms appear [13].

Our study did not find homo or bisexual patients at high risk of late presentation. This result is consistent with the literature $[14,15]$, where heterosexual contact is risk factor of presentation for care with low CD4 cell count. The authors reported that heterosexual men were at high risk of presentation for care with either symptoms of clinical AIDS or CD4 cell count $<200 / \mathrm{mm}^{3}$ during the year of diagnosis. This association could be explained by the fact that heterosexuals are often unaware of their HIV infection. In contrary, a French multicentric population study [16] found that homo or bisexuals patients were at high risk of late access to care. The fact that MSM are tested later may reflect the adverse consequences of stigma and discrimination in this vulnerable population group.

Several studies $[6,7,10,17,18]$ reported migrants from highprevalence countries according to the World Health Organization (WHO) definition [19] in the group with the highest proportion of patients with late diagnosis. In our study this variable was not statistically significant. This difference could be attributed to the very small number of subjects in this group. In French Guiana, the risk factors for delayed HIV diagnosis were age, male sex, and foreign nationality [7]. Consistent with previous studies, our findings show that older patients, heterosexuals, men and patients who initiated care before 1992 were more likely to be diagnosed late with advanced HIV disease [6-10]. However, for many variables such as depression, use of drug or foreign nationality, there was a very small number of subjects due to missing data, they do not appear as risk factors.

Late presentation is associated with a substantially higher risk of mortality and morbidity. The risk increases with lower CD4 cell counts at ART initiation and remains elevated even years after initiation of ART [20,21]. This argues for early diagnosis and treatment of HIV infection, before patients enter advanced stages of immunodeficiency. In contrast to many developing countries, access to HIV testing and treatment currently is not limited by economic constraints in Overseas French Departments such as Guadeloupe. As a basis for targeted interventions, we tried to identify groups at risk for late diagnosis and care.

Our results may be of interest for other French American Departments, because the population characteristics and local HIV screening practices are similar in these countries [22-29].

This study has several limitations and the limited number of explanatory variables that need to be considered when interpreting the data. First, although most of our results are consistent with previous studies, some potential risk factors, such as education, HIV knowledge and awareness, religion affiliations, employment status, were not 
Citation: Elenga N, Georger-Sow M-T, Nacher M (2012) Risk Factors for Late Presentation for Care among HIV-Infected Patients in Guadeloupe: 19882009. J AIDS Clinic Res 3:166. doi:10.4172/2155-6113.1000166

recorded. Second, although all data were collected prospectively, the study was designed after data collection had ended. Third, the monocentric character of this study limits its external validity. Despite the above limitations, this analysis offers the only data for the territory of Guadeloupe on the problem of delayed access to diagnosis and care in HIV- infected adult patients.

In summary, in Guadeloupe, despite efforts in the field, $40.12 \%$ of HIV-infected patients reach the health care system with CD4 cell count $<200 / \mathrm{mm}^{3}$ and this proportion remained stable since 2000-2003. As French authorities now recommend rapid testing as screening method and systematic proposal of an HIV test for everyone, prevention campaigns must target populations at high risk, in addition to screening of the general population.

\section{Conclusion}

In conclusion, this analysis of data from the GFHDH suggests a persistently high proportion of late presenters for HIV diagnosis and for HIV care in Guadeloupe. In addition to diagnosing HIV infection earlier, patients should be referred to a specialized treatment centre earlier than was the case in the period analysed.

The findings of this study may be of value in helping to achieve earlier access to treatment in HIV-infected patients in order to minimize the individual risk of morbidity and mortality.

\section{Acknowledgments}

The authors would like to thank the members of the guadeloupean HIV Cohort Study for data collection.

\section{References}

1. CAREC/PAHO/WHO (2007) The Caribbean HIVIAIDS Epidemic and the situation in member countries of the Caribbean Epidemiology Centre (CAREC).

2. Camara B (2006) 20 Years of the HIVIAIDS Epidemic in the Caribbean: A Summary by $\mathrm{Dr}$ B. Camara, Medical Epidemiologist--PAHO/WHO, Head CAREC - SPSTI

3. Gazzard B, Lundgren J (eds.) (2008) The HIV in Europe 2007 initiative: issues, challenges and opportunities for addressing optimal testing and earlier care. HIV Med 9: 1-40.

4. Antinori A, Coenen T, Costagiola D, Dedes N, Ellefson M, et al. (2011) Late presentation of HIV infection: a consensus definition. HIV Med 12: 61-64.

5. Bilan démographique (2009) INSEE Première $\mathrm{N}^{\circ}$ 1276- Janvier 2010.

6. Zoufaly A, an der Heiden M, Marcus U, Hoffmann C, Stellbrink H, et al. (2012) Late presentation for HIV diagnosis and care in Germany. HIV Med 13: 172181.

7. Nacher M, El Guedj M, Vaz T, Nasser V, Randrianjohany A, et al. (2005) Risk factors for late HIV diagnosis in French Guiana. AIDS 19: 727-729.

8. Lo YC, Wu PY, Hsieh CY, Chen MY, Sheng WH, et al. (2011) Late diagnosis of human immunodeficiency virus infection in the era of highly active antiretroviral therapy: role of socio-behavioral factors and medical. J Formos Med Assoc 110: 306-315.

9. Nhac-Vu HT, Giard M, Phong ND, Vanhems P (2010) Risk factors for delayed HIV diagnosis at the Hospital of Tropical Diseases in Ho Chi Minh City, Vietnam. Int J STD AIDS 21: 802-805.

10. Ndiaye B, Salleron J, Vincent A, Bataille P, Bonnevie F, et al. (2011) Factors associated with presentation to care with advanced HIV disease in Brussels and Northern France: 1997-2007. BMC Infect Dis 11: 11.
11. Borghi V, Girardi E, Bellelli S, Angeletti C, Mussini C, et al. (2008) Late presenters in an HIV surveillance system in Italy during the period 1992-2006. J Acquir Immune Defic Syndr 49: 282-286.

12. Baratin D, Marceillac E, Trepo C, Cotte L, Peyramond D, et al. (2004) Characteristics of patients diagnosed with AIDS shortly after first detection of HIV antibodies in Lyon University hospitals from 1985 to 2001. HIV Med 5 273-277.

13. Krawczyk CS, Funkhouser E, Kilby JM, Vermund SH (2006) Delayed access to HIV diagnosis and care: Special concerns for the Southern United States. AIDS Care 18: S35-S44.

14. Girardi E, Sabin CA, Monforte AD (2007) Late diagnosis of HIV infection: epidemiological features, consequences and strategies to encourage earlier testing. J Acquir Immune Defic Syndr 46: S3-S8.

15. Torian LV, Wiewel EW, Liu KL, Sackoff JE, Frieden TR (2008) Risk factors for delayed initiation of medical care after diagnosis of human immunodeficiency virus. Arch Intern Med 168: 1181-1187.

16. Delpierre C, Cuzin L, Lauwers-Cances V, Marchou B, Lang T (2006) High-Risk groups for late diagnosis of HIV infection: a need for rethinking testing policy in the general population. AIDS Patient Care STDS 20: 838-847.

17. Couturier E, Schwoebel V, Michon C, Hubert JB, Delmas MC, et al. (1998) Determinants of delayed diagnosis of HIV infection in France, 1993-1995. AIDS 12: $795-800$.

18. Turner BJ, Cunningham WE, Duan N, Andersen RM, Shapiro MF, et al. (2000) Delayed medical care after diagnosis in a US national probability sample of persons infected with human immunodeficiency virus. Arch Intern Med 160: 2614-2622.

19. UK Collaborative HIV Cohort (UK CHIC) Steering Committee, Sabin CA Schwenk A, Johnson MA, Gazzard B, et al. (2010) Late diagnosis in the HAART era: proposed common definitions and associations with mortality. AIDS 24 723-727.

20. Deloumeaux J, Foucan L, Sow-Goerger MT, Contamin B, Strobel M (2000) Trends of AIDS in Guadeloupe (French West Indies) a longitudinal survey from 1988 to 1997. West Indian Med J 49: 148-153.

21. Egger M, May M, Chene G, Phillips AN, Ledergerber B, et al. (2002) Prognosis of HIV-1-infected patients starting highly active antiretroviral therapy: a collaborative analysis of prospective studies. Lancet 360: 119-129.

22. Antiretroviral Therapy Cohort Collaboration (2007) Importance of baseline prognostic factors with increasing time since initiation of highly active antiretroviral therapy: collaborative analysis of cohorts of HIV-1-infected patients. J Acquir Immune Defic Syndr 46: 607-615.

23. Pourette D (2011) Pregnancy and medical follow-up of women living with HIV AIDS in Guadeloupe and Martinique (French West Indies): medical progress and social problems. Sante 21: 9-14.

24. Cabie A, Georger-Sow MT, Nacher M (2005) Particularités de l'infection a VIH aux Antilles et en Guyane française en 2004. BEH n 46-47: 238-239.

25. Nacher M, Adriouch L, Adenis A, Hanf M, Van Melle A, et al. (2011) Risk factors for delayed access to specialized care in French Guiana. Am J Trop Med Hyg 84: 806-807.

26. Cazein F, Le Strat Y, Pillonel J, Lot F, Bousquet V, et al. (2011) Depistage du VIH et découvertes de séropositivité, France, 2003-2010. BEH 43-44: 446-454

27. Nacher M, Vantilcke V, Parriault MC, Van Melle A, Hanf M, et al. (2010) What is driving the HIV epidemic in French Guiana? Int J STD AIDS 21: 359-361.

28. Nacher M, Adenis A, Hanf M, Adriouch L, Vantilcke V, et al. (2009) Crack cocaine use increases the incidence of AIDS-defining events in French Guiana. AIDS 23: 2223-2226.

29. Nacher M, Huber F, El Guedj M, Vaz T, Magnien C, et al. (2007) Risk factors for death among patients in French Guiana: 1996-2005. HIV Med 8: 472-474. 